\title{
Autophagy-Related Protein 13
}

National Cancer Institute

\section{Source}

National Cancer Institute. Autophagy-Related Protein 13. NCI Thesaurus. Code C126137.

Autophagy-related protein 13 (517 aa, $\sim 57 \mathrm{kDa}$ ) is encoded by the human ATG13 gene.

This protein plays a role in the modulation of autophagy. 